July 1984

\title{
Psychosis in a Patient with Autoimmune Deficiency Syndrome
}

Vivian Charneco, MD

Thomas Jefferson University Hospital

Follow this and additional works at: https://jdc.jefferson.edu/jeffjpsychiatry

Part of the Psychiatry Commons

Let us know how access to this document benefits you

\section{Recommended Citation}

Charneco, MD, Vivian (1984) "Psychosis in a Patient with Autoimmune Deficiency Syndrome," Jefferson Journal of Psychiatry. Vol. 2 : Iss. 2 , Article 4.

DOI: https://doi.org/10.29046/JJP.002.2.003

Available at: https://jdc.jefferson.edu/jeffjpsychiatry/vol2/iss2/4

This Article is brought to you for free and open access by the Jefferson Digital Commons. The Jefferson Digital Commons is a service of Thomas Jefferson University's Center for Teaching and Learning (CTL). The Commons is a showcase for Jefferson books and journals, peer-reviewed scholarly publications, unique historical collections from the University archives, and teaching tools. The Jefferson Digital Commons allows researchers and interested readers anywhere in the world to learn about and keep up to date with Jefferson scholarship. This article has been accepted for inclusion in Jefferson Journal of Psychiatry by an authorized administrator of the Jefferson Digital Commons. For more information, please contact: JeffersonDigitalCommons@jefferson.edu. 


\title{
PSYCHOSIS IN A PATIENT WITH AUTOIMMUNE DEFICIENCY SYNDROME
}

\author{
VIVIAN CHARNECO, M.D.
}

\section{Introduction}

Autoimmune deficiency syndrome (AIDS) is a disease whose incidence has grown precipitously in recent years. Its victims face social and psychological isolation (1). Contributing to this isolation is the fear of contact with AIDS patients that exists among health care workers and the public (2).

Increasingly more is being understood about this mysterious disease. Recent reports have supported a viral etiology. The chief criterion for diagnosis is an inverted helper to suppressor T-cell ratio. Other supportive findings include lymphopenia, leukopenia, elevated IgA levels, and anergia. The following case report highlights the neurological and psychiatric symptoms that may be seen in a patient with AIDS.

\section{Case Report}

The patient was a 48-year-old male with no prior psychiatric history. He was brought to a psychiatric emergency room by his family, who complained of a three day history of increasing insomnia and agitation, as well as an unusual preoccupation with working in his basement. About four hours prior to presentation the patient was noted to have become increasingly disorganized, was speaking incoherently, and began engaging in purposeless behavior such as banging his head against the tub. When the patient's family tried to stop him from banging his head, he became combative. Ultimately the police were called so that he could be transported to the hospital.

Further history obtained from the patient's family was significant for a ten pound weight loss over the last three months following rectal surgery for what was diagnosed as condiloma acuminata. Subsequent to this surgery, the patient developed diarrhea with secondary mild hypokalemia. Additionally he had a long standing history of hypertension. During the three weeks prior to presentation he was reported to have suffered from an upper respiratory infection associated with occasional coughing. The family denied any history of drug and alcohol abuse, or homosexual activity. Prior to this sudden change in his behavior, the patient had been attending his job as a maintenance worker regularly.

Initial mental status examination was remarkable for an agitated, uncooperative male who was disoriented in all spheres and was mumbling incoherently. He displayed echolalia, stared off into space purposelessly, and postured in bizarre manners at times. An attempt to evaluate his cognition was unsuccessful.

The patient was treated with $10 \mathrm{mg}$. of haloperidol given intramuscularly in an

Dr. Charneco is third-year resident in psychiatry. 
attempt to control his agitated behavior. He responded well, becoming remarkably less agitated. Within eight hours his sensorium began to clear. He became increasingly oriented, was goal-directed in his behavior, and began to have partial recall of events from earlier in the day.

Concomitant medical workup revealed an oral temperature of $103^{\circ} \mathrm{F}$. A complete blood count with differential and serum electrolyte values were within normal limits except for a potassium level of $2.8 \mathrm{mEq} / \mathrm{L}$. Drug screen was negative. A chest X-ray revealed a diffuse pulmonary infiltrate, and at that time the patient was admitted to the medical service. Subsequent bronchoscopy revealed Pneumocystis carinii. Later studies revealed $2 \% \mathrm{~T}$-cell helper (normal range $45 \% \pm 11 \%$ ) and $66 \% \mathrm{~T}$-cell suppressor (normal range $28 \% \pm 8 \%$ ) concentrations.

Two days after admission a psychiatric evaluation revealed no remarkable mental status abnormalities, in contrast to his initial presentation. The psychiatric consultation team continued to follow this patient, who displayed no further evidence of psychosis, although he became very anxious when he was told that he had autoimmune deficiency syndrome some nine days after admission.

\section{DISCUSSION}

Neurologic and psychiatric symptoms are sometimes found in patients with AIDS. Two patterns of neurological involvement have been described (3). One is characterized by symptoms of focal disease, and may be attributed to specific etiologic agents such as Toxoplasma (4). Bedri and Weinstein have described an AIDS patient who developed progressive multifocal leukoencephalopathy whose symptoms included confusion, gait disturbance, urinary incontinence, memory and attention deficits (5). These symptoms are among those described by the American Neurological Association that can be associated with AIDS (3). Other notable symptoms are progressive dementia, seizures, inappropriate antidiuretic hormone secretion, hallucinations, parasthesias, paresis, and coma vigil. While in some instances a focal etiology may be described, in others no neuropathological changes can be correlated with the symptoms. In those patients who characteristically present with psychiatric symptoms, no focal pathology may exist, although a higher percentage of microglial nodules and Alzheimer type II cells has been found in some of these patients' brains (3).

In the patient presented there was no recurrence of psychiatric symptoms despite repeated temperatures as high as $103^{\circ} \mathrm{F}$. Because no further neurological workup was done, no conclusive statements can be made as to the etiology of his agitated behavior. It is tempting to suggest that his symptoms, which may have been attributable to septicemia, were the result of non-focal involvement of the CNS. In any event, it behooves us as psychiatrists to have a fuller understanding of how AIDS may effect or present in the patients we treat.

\section{REFERENCES}

1. Holtz H, Dobro J, et al: Psychosocial impact of acquired immune deficiency syndrome. JAMA 250: 167, 1983 
2. Weiss K: AIDS: Turmoil in the medical profession. The New Phys 32: 13-17, 1983

3. Gapen P: Neurological complications now characterizing many AIDS victims. JAMA 248: 2941-2942, 1982

4. Post MJ, Chan JC: Toxoplasma encephalitits in Haitian adults with acquired immunodeficiency syndrome: a clinical, pathologic CT correlation. Am J Roen 140: 861-868, 1983

5. Bedri J, Weinstein W, et al: Progressive multifocal leuko-encephalopathy in acquired immunodificiency syndrome. New Engl J Med 309: 492-493, 1983 